\title{
COUNTERSINKING FOR TREE BOLTS
}

\author{
by E. Thomas Smiley
}

\begin{abstract}
When installing eyebolts and brace rods, the practice of countersinking into the xylem tissue using a chisel is common. This study was developed to assess an alternative method of cutting countersinks and to determine which method has the lower potential for introducing decay. It was determined that seating the washer on the bark rather than countersinking into the xylem produced the lowest levels of discolored wood and the lowest amounts of callus growth over washers. Data from this study support the recommendation that countersinking into the xylem be discontinued.
\end{abstract}

Bolts are installed in trees to strengthen weak crotches and to anchor cable systems (Thompson 1959; Mayne 1975; Harris 1983). It is standard practice to countersink through the bark and into the wood so that the washer beneath the nut is firmly seated on wood. Countersinking is usually done using a gouge and mallet to outline and remove the bark and some wood. Recommendations for countersinking specify cutting to a depth of $1 / 8$ in. $(3 \mathrm{~mm}$ ) below the cambium (Thompson 1959; NAA 1970) .

There are several potential problems with countersinking. First, drilling holes for J-hook lags causes discoloration of the wood, although decay is well compartmentalized (Shigo and Felix 1980). Cutting a larger hole for the washer is similar to turning a J-hook lag into the bark, a situation that Shigo and Felix warn may cause the spread of decay.

Second, countersinking can be a timeconsuming procedure, often adding 10 minutes per bolt to an installation (Joseph Bones, F.A. Bartlett Tree Expert Co., personal communication). If this can be reduced, the client can save money on the installation. To potentially speed countersinking, a Forstner-type drill bit can be used, rather than chisel.

This study compares the potential for decay and wound closure for bolts installed with coun- tersink holes that were either drilled or gouged and bolts installed without countersinking.

\section{Materials and Methods}

Three American beeches (Fagus grandifolia), 11 to $30 \mathrm{~cm} \mathrm{(4.5} \mathrm{to} 12 \mathrm{in}$.) diameter at $4.5 \mathrm{ft}$, and 3 red oaks (Quercus rubra), 29 to $39 \mathrm{~cm}$ ( 11.5 to $15.5 \mathrm{in}$.) diameter were selected in a wooded area at the Bartlett Tree Research Laboratories in Charlotte, NC. The lower trunk of each tree was drilled 6 times in a spiral pattern. The holes were $0.95 \mathrm{~cm}$ (3/8 in.) diameter and were drilled $5 \mathrm{~cm}$ (2 in.) deep using a spade bit to accommodate a $5 \mathrm{~cm}$ (2 in.) long, $1.3 \mathrm{~cm}$ (1/2 in.) diameter lag screw. Lag screws with washers were used in place of bolts with washers to avoid drilling all the way through the trees and to simulate the effects of countersinking and not countersinking in bolt installation. Each hole was randomly assigned 1 of 3 treatments: 1) countersinking into xylem to a depth of $3 \mathrm{~mm}$ (1/8 in.) using a gouge, 2) countersinking to a depth of $3 \mathrm{~mm}(1 / 8 \mathrm{in}$.) using a Forstner drill bit, and 3 ) a control that was not countersunk. Forstner bits quickly cut a flatbottomed hole with cleanly cut sides. Washers $3.5 \mathrm{~cm}(1-3 / 8 \mathrm{in}$.) diameter were installed with each lag. All lags were torqued to 54 Newtonmeters (40 foot-pounds).

Lags were installed on April 25, 1995. Callus overgrowth of the washers was measured on June 11, 1996, and lags were removed on June $12,1996$.

Wood discoloration precedes wood decay in most cases and becomes evident much more quickly than decay. Therefore, discoloration of the wood around countersunk holes was used to compare the levels of damage to the tree. After lag removal, the bark and sapwood were removed tangentially from the area around the lag to re- 
veal the area of wood discoloration. This area was traced onto a clear plastic sheet, cut out of the sheet, and weighed to determine the area of discoloration.

\section{Results}

The time required to drill countersink holes was considerably less than chiseling. However, even less time was consumed by not countersinking (data not shown).

Approximately half of the red oaks that were countersunk exhibited an oozing from the margin of the holes. There was also noticeable dieback of the cambium on the chiseled holes. Dieback was not observed on the drilled countersink holes.

With both oak and beech, discoloration of the wood was more than doubled by using either of the countersinking methods compared to the notcountersunk treatment (Table 1). Callus growth over the washer on the drilled countersunk oak was significantly greater than both the chiseled treatments and the control (not countersunk). With beech there was no difference between countersinking methods. However, both produced more callus than the not-countersunk control.

\section{Conclusions}

While countersinking is traditionally used when bolts are installed, it is apparent that this practice significantly increases the amount of discoloration. Therefore, it is recommended that the practice of countersinking into the wood of a trunk or limb when installing eyebolts or brace rods be discontinued as a routine practice. When installing brace rods on very thick-barked trees, it still may be desirable to countersink the outer bark so that there is no movement of the rod.

Callus growth over a washer is considered advantageous from an aesthetic point of view. However, it plays no part in the holding strength of the bolt. The benefits of countersinking in order to accelerate callus growth do not outweigh the increased potential for introducing decay.
Table 1. Callus growth over washers and area of wood discoloration one year after lag and washer installation using 2 methods of countersinking and not countersinking.

\begin{tabular}{llll}
\hline $\begin{array}{l}\text { Tree } \\
\text { species }\end{array}$ & $\begin{array}{l}\text { Type of } \\
\text { counter- } \\
\text { skinking }\end{array}$ & $\begin{array}{l}\text { Callus } \\
\text { growth } \\
(\mathrm{mm})\end{array}$ & $\begin{array}{l}\text { Wood } \\
\text { discoloration } \\
\left(\mathrm{cm}^{2}\right)\end{array}$ \\
\hline Red oak & drill & $8.5 \mathrm{a}^{*}$ & $28.3 \mathrm{a}$ \\
& chisel & $4.1 \mathrm{~b}$ & $38.6 \mathrm{a}$ \\
Beech & none & $0.2 \mathrm{c}$ & $14.4 \mathrm{~b}$ \\
& drill & $10.2 \mathrm{a}$ & $17.6 \mathrm{a}$ \\
& chisel & $8.8 \mathrm{a}$ & $19.4 \mathrm{a}$ \\
& none & $0.0 \mathrm{~b}$ & $8.7 \mathrm{~b}$ \\
\hline
\end{tabular}

*Means in the same column and species with the same letter are not significantly different $(P=0.05)$ according to the Student Newman Kuels test.

\section{Literature Cited}

Harris, R.W. 1983. (2nd ed.) Arboriculture: Integrated Management of Landscape Trees, Shrubs, and Vines. Prentice Hall, Englewood Cliffs, NJ. $674 \mathrm{pp}$.

Mayne, L.S. 1975. Cabling and bracing. J. Arboric. 1:101-105.

National Arborist Association. 1970. Bracing, cabling and guying standard for shade trees. NAA, Amherst, NH. 4 pp.

Shigo, A.L., and R. L. Felix. 1980. Cabling and bracing. J. Arboric. 6:5-9.

Thompson, A.R. 1959. Tree bracing. National Park Service Tree Preservation Bull. No. 3. Washington DC. $21 \mathrm{pp}$.

Acknowledgements. Thanks to Bruce $R$. Fraedrich, Stephen W. Smith, Lynn Roberts, Joseph Bones, and Walt Dages for their contributions to this paper.

Bartlett Tree Research Lab

13768 Hamilton Road

Charlotte, NC 28278 
Résumé. Lors de l'installation des boulons à œil, écrous et des rondelles pour le haubanage rigide, il est fréquent de sculpter le xylème autour avec un ciseau à bois. Cette étude cherche à comparer les effets de sculpter ou de fraiser le xylème versus de ne pas le faire sur l'incidence potentielle de l'introduction de carie dans le bois. On y conclut qu'appuyer la rondelle contre l'écorce plutôt que contre le xylème produit le plus faible taux de décoloration du bois et une plus petite quantité de cal cicatriciel autour de la rondelle. Les données recueillies dans cette étude permettent de recommander que le sculptage jusqu'au xylème soit aboli.

Zusammenfassung. Wenn Schraubhaken und Kabel installiert werden, wird gewöhnlich ein Stemmeisen gebraucht, um die Kontermutter und Unterlegscheibe in Splintholz zu versenken. Diese Studie vergleicht das Bohren und Herausstemmen der Konterlöcher mit der Installation von Ösen ohne Gegenloch um zu bestimmen, welche Methode am wenigsten Fäule verursacht. Es kam heraus, daß das Plazieren der Unterlegscheibe auf der Borke im Gegensatz zum Versenken in das Splintholz den niedrigsten Level an Holzverfärbungen und die geringste Kallusbildung über der Unterlegscheibe verursacht. Die Daten aus dieser Studie unterstützen die Empfehlung, die Versenkung in das Splintholz nicht weiter durchzuführen.

Resumen. Cuando se instalan pernos y pasadores, es común la práctica de perfilar dentro del tejido del xilema usando un cincel. Este estudio compara la instalación de tornillos con agujeros taladrados y perfilados con cincel, contra su instalación sin perfilar, para determinar cual método tiene el más bajo potencial para introducir decaimiento. Se determinó que instalar la arandela directamente sobre la corteza en lugar de perfilar dentro del xilema produjo los niveles más bajo de madera decolorada y menos cantidad de callo creció sobre las arandelas. Los datos de este estudio sostienen la recomendación de que el perfilado dentro del xilema no debe continuar. 